\title{
The freedom to choose: integrating community- based reproductive health services with locally led marine conservation initiatives in southwest Madagascar
}

Laura Robson, Fanjavola Rakotozafy

\section{ABSTRACT}

Madagascar's diverse marine ecosystems serve as critical biodiversity habitats and are also essential to the livelihoods, food security and culture of coastal people, including semi-nomadic Vezo fishers based along the southwest coast. Commercialisation of their traditional fisheries, rapid coastal population growth related to unmet family planning needs, and lack of alternatives to fishing in this arid region are resulting in the unsustainable exploitation of coastal resources. In response to these challenges, marine conservation organisation Blue Ventures has developed an approach to community-based conservation and development that reflects the inextricable links between humans, their health and the environment. We describe how this model has evolved in the Velondriake locally managed marine area, home to approximately 10,000 people, over the last decade through strong cross-sector partnerships. It has entailed the integration of community-based reproductive health services with locally led marine conservation initiatives including temporary octopus fishery closures, permanent marine reserves and alternative coastal livelihood activities such as aquaculture. All of these programmes are underpinned by community education that engages men, women, youth and children in both health and conservation topics. The provision of voluntary family planning services in the velondriake area is estimated to have averted more than 800 unintended pregnancies since 2007, and the temporary octopus fishery closure model has been implemented over 150 times along the southwest coast since 2004. Preliminary, anecdotal reports from community members and programme staff indicate that this integrated Population-Health-Environment approach enables couples to plan and better provide for their families, empowers women, improves food security and directly supports the sustainability of local conservation efforts. It is proving to be an easily replicable model for addressing community health needs and advancing biodiversity conservation efforts in some of Madagascar's most remote and under-served areas.

\section{RÉSUMÉ}

Non seulement les écosystèmes marins de Madagascar abritentils une biodiversité exceptionnelle mais ils sont également
Correspondence:

Laura Robson

Blue Ventures Conservation, Madagascar

E-mail: laura@blueventures.org

intrinsèquement liés au mode de vie et à la sécurité alimentaire des populations côtières, notamment des pêcheurs seminomades qui vivent le long de la côte sud-ouest. La commercialisation des produits de la pêche traditionnelle, la croissance rapide de la population qui est en partie liée à des défauts en matière de planification familiale et l'absence d'alternatives à la pêche dans cette région aride se traduisent par une exploitation non durable des ressources côtières. Pour trouver une solution à cette situation, I'organisation de conservation marine Blue ventures a élaboré une approche holistique qui considère les liens obligés entre les Hommes, leur santé et l'environnement. L'évolution du modèle élaboré pour I'aire marine de Velondriake est décrite ici ; elle concerne environ 10000 personnes au cours de cette dernière décennie et des partenariats multisectoriels. Le modèle a intégré des services de santé reproductive avec des initiatives de conservation marine gérées localement, comme des fermetures temporaires de la pêche aux poulpes, des réserves marines permanentes et des activités génératrices de revenus telles que l'aquaculture. L'ensemble de ces programmes est soutenu par des actions d'éducation en mobilisant les hommes, femmes, jeunes et enfants sur des thèmes aussi variés que la santé ou la protection de l'environnement. Ainsi, on estime que la prestation des services de planification familiale volontaire dans la région de Velondriake a pu éviter plus de 800 grossesses non désirées depuis 2007, et des fermetures temporaires de la pêche aux poulpes plus de 150 fois le long de la côte sud-ouest depuis 2004. Des rapports préliminaires et anecdotiques de membres des communautés et des personnels du programmes indiquent que cette approche intégrée "Santé - Population - Environnement " permet aux couples de planifier et de mieux subvenir aux besoins de leurs familles, aux femmes de s'émanciper et aux familles d'améliorer leur sécurité alimentaire tout en soutenant directement la durabilité des activités de conservation marine gérées localement. Ce modèle s'est révélé être facilement reproductible pour répondre aux besoins de santé communautaire et pour faire avancer les efforts de conservation de la biodiversité dans les régions les plus reculées et les plus isolées de Madagascar. 


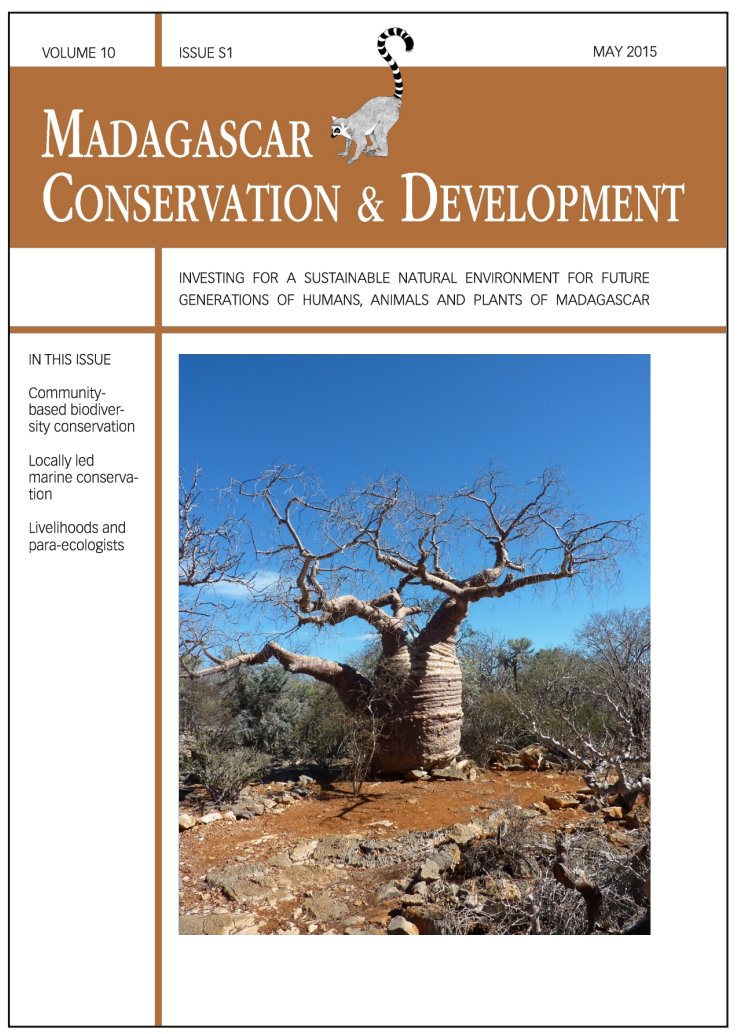

Madagascar Conservation \& Development is the journal of Indian Ocean e-Ink. It is produced under the responsibility of this institution. The views expressed in contributions to MCD are solely those of the authors and not those of the journal editors or the publisher.

All the Issues and articles are freely available at http://www.journalmcd.com

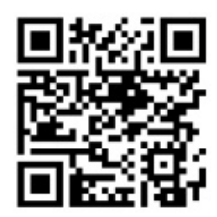

Contact Journal MCD

info@journalmcd.net for general inquiries regarding MCD funding@journalmcd.net to support the journal

Madagascar Conservation \& Development Institute and Museum of Anthropology

University of Zurich

Winterthurerstrasse 190

$\mathrm{CH}-8057$ Zurich

Switzerland

Indian Ocean e-Ink

Promoting African Publishing and Education

www.ioeink.com

Missouri Botanical Garden (MBG)

Madagascar Research and Conservation Program

BP 3391

Antananarivo, 101, Madagascar 


\section{INTRODUCTION}

With $80 \%$ of its species found nowhere else on earth, Madagascar is renowned globally as a biodiversity hotspot. The country's vast array of unique flora and fauna does not stop at its shores, with over $5,500 \mathrm{~km}$ of coastline spanning more than 14 degrees of latitude, harbouring a diversity of marine and coastal habitats that is unparalleled in the Indian Ocean (Harris 2011). Madagascar's southwest coast hosts one of the largest coral reef systems in the region (Cooke et al. 2000), which not only serves as critical marine biodiversity habitats, but is also essential to the survival of the local coastal population; semi-nomadic fishing communities known as the Vezo, or 'people of the sea', who depend on the marine environment for food, income and cultural identity (Astuti 1995).

SMALL-SCALE FISHERIES: NOT SO SMALL AFTER ALL.

Velondriake is a locally managed marine area in the district of Morombe that spans more than $750 \mathrm{~km} 2$ and is home to approximately 10,000 people (Harris 2007). $87 \%$ of adults in this region are fishers or gleaners (Barnes-Mauthe et al. 2013). Locally caught seafood, primarily fin fish, constitutes the sole protein source in $99 \%$ of all household meals with protein (Barnes-Mauthe et al. 2013). Small-scale fisheries are the economic lifeblood of Velondriake communities, yielding an estimated value of almost \$US7 million in 2010. This includes both commercial sales, accounting for $83 \%$ of the total (with fin fish, octopus and sea cucumber being the most important species), and also subsistence catch (Barnes-Mauthe et al. 2013). Unsustainable fishing pressure is mounting on these marine ecosystems, due in part to the commercialisation of the region's traditional smallscale fisheries over the last decade (L'Haridon 2006). The arrival of international seafood collection companies has connected remote coastal communities with higher paying export markets, leading to an increase in the value and associated exploitation of fresh octopus and other target species (L'Haridon 2006, Harris 2007).

UNMET FAMILY PLANNING NEEDS AND POPULATION GROWTH. The coastal population is growing more rapidly in this region compared to the country as a whole, and is expected to double within 10-15 years (Harris et al. 2012). This trend is fuelled in part by high levels of migration from arid inland zones where agricultural productivity and employment opportunities are severely limited (Harris 2011). Fertility rates are also high, with women in the Atsimo-Andrefana region (where the Velondriake area is located) giving birth to an average of 6.2 children, compared to the national average of 4.8 (INSTAT 2010). The nation's demographic structure is heavily positively skewed, with almost $50 \%$ of the population aged under 15 years (INSTAT 2010). This reflects significant population growth and increasing anthropogenic pressure on natural resources.

High fertility rates may be explained by limited access to reproductive health services in this region (Harris et al. 2012). People living in isolated communities in rural Atsimo-Andrefana have to travel up to $50 \mathrm{~km}$ to reach the nearest public health centres, most of which are under-staffed and under-stocked. Government spending on health was reduced by more than half during the country's political impasse in 2009-2013 (IRIN News 2012), resulting in the closure of numerous clinics and a decline in the national contraceptive prevalence rate (UNFPA Madagascar Country Representative, pers. comm.), which stood at just 29\% in 2008-9 (INSTAT 2010).

Almost a quarter of women in Atsimo-Andrefana reported unmet family planning needs prior to the political upheaval and budget cuts (INSTAT 2010), resulting in negative impacts on maternal and child health outcomes. Malagasy women face a 1 in 45 lifetime risk of maternal death (UNFPA 2011), and 112 children per 1,000 live births die before their fifth birthday in AtsimoAndrefana, which is almost double the national average of 62 (INSTAT 2010). Addressing unmet family planning needs and enabling women to space their births can reduce maternal and child mortality by at least $25 \%$ in such contexts (Setty-Venugopal and Upadhyay 2002, Ahmed et al. 2012, Agarwal 2013). It can also help to address gender inequity and alleviate poverty (USAID et al. 2009), as the inability to make their own reproductive health choices marginalises women and places significant economic burdens on families (Harris et al. 2012, Westerman et al. 2012).

UNSUSTAINABLE EXPLOITATION OF COASTAL RESOURCES.

With growing numbers of mouths to feed, and commercial markets driving further exploitation, fishing activity is on the rise (L'Haridon 2006, Le Manach et al. 2012). Recent evidence suggests that national catches have been under-reported by as much as 500\% since 1950 (Le Manach et al. 2012). Small-scale artisanal and subsistence fishers have been particularly overlooked, accounting for $72 \%$ of total catches in the 2000 s (Le Manach et al. 2012). Such yields are not sustainable and signs of decline have already been observed in several stocks, in particular those collected through reef gleaning (ibid). Meanwhile, institutional capacity for monitoring fisheries and managing marine areas is severely limited, with few available resources and significant infrastructural challenges in reaching thousands of kilometres of extremely remote coastline (Harris 2011). Consequently, almost nothing is known about the scale of illegal, unreported and unregulated fishing in Madagascar's exclusive economic zone (EEZ); the nation's fishery surveillance centre has just three monitoring vessels, 8 speedboats, 18 inspectors and 22 observers to patrol an area almost twice the size of France (Le Manach et al. 2012).

All of these factors - the commercialisation of traditional fisheries, coastal population growth, unmet family planning needs, limited access to reproductive health services, lack of alternatives to fishing in the arid southwest, and inadequate management capacity - are converging to result in the unsustainable exploitation of coastal resources, which in turn is threatening the diverse marine ecosystems upon which vezo livelihoods, food security and culture depend.

This paper documents the evolution of an integrated approach to community-based conservation and development in southwest Madagascar, developed by marine conservation organisation Blue Ventures in response to the interconnected challenges of unmet reproductive health needs, food insecurity, unsustainable resource use and environmental degradation in this region. The model combines voluntary family planning services with locally led conservation initiatives including temporary octopus fishery closures, permanent marine reserves and alternative coastal livelihood activities such as aquaculture.

We have started by outlining the rationale for this approach in terms of the environmental, economic and social context in which this model has been developed. Next we describe how Blue Ventures' locally led marine resource management, alternative coastal livelihood and reproductive health programmes 
have evolved in this region over the last decade, including important lessons learned and adaptations made by each initiative. Then we describe how the integration of these different activities works in practice, from all-round community education to coordinated field missions. Next we outline the multifaceted impacts of this model, as experienced and reported by community members and programme staff. We conclude by noting the significant potential for replicating this integrated approach in other biodiverse and under-served areas of Madagascar, particularly through cross-sector partnerships.

\section{APPROACH}

TEMPORARY FISHERY CLOSURES: A FOOT-IN-THE-DOOR FOR MARINE CONSERVATION. Blue Ventures first started working with the coastal village of Andavadoaka in 2003, in collaboration with the University of Toliara's Institut Halieutique et des Sciences Marines (IHSM) and the Wildlife Conservation Society (WCS), holding meetings with fishers to discuss the state of their marine resources and options for more sustainable management. In October 2004, community leaders decided to establish a dina or local law, to implement a temporary closure of approximately $15 \%$ of their fishing grounds for several months (Harris 2007). The restriction only applied to Octopus cyanea, one of the village's most important commodities and a very rapidly growing species, which was therefore predicted to respond well to short-term management efforts.

Results from the first experimental octopus fishery closure, implemented between November 2004 and June 2005 with endorsement from seafood collection company copefrito, were very promising (Harris 2007). The temporary closure boosted octopus landings and fisher incomes upon opening, resulting in an unprecedented groundswell of community interest in more ambitious marine resource management efforts (ibid). Nevertheless, catch per unit effort (CPUE) did not increase as expected following this first trial closure; an unanticipated outcome attributed to intense activity by visiting fishers ('free-riders') on the days following the reserve opening (Benbow et al. 2014). This compelled people in Andavadoaka to encourage neighbouring villages to organise their own temporary closures.

As the temporary octopus fishery closure model began to spread along the coastline, representatives from 25 villages in the region came together in Andavadoaka between July and October 2006 to propose a series of dina for creating a network of marine and coastal protected areas, and banning destructive practices such as poison fishing and beach seining, with community-based monitoring and locally enforced fines for infractions (Harris 2007, Andriamalala and Gardner 2010). The aim of the network is to safeguard biodiversity while improving livelihoods. It encompasses permanent coral reef and mangrove reserves, temporary octopus fishery closures, special areas for aquaculture and ecotourism, and protected dry forest zones with Adansonia grandidieri baobab trees. This locally managed marine area (LMMA), called Velondriake, which means "to live with the sea", covers more than $750 \mathrm{~km} 2$ and is governed by a management committee consisting of members elected from every village in the network (Harris 2007, Mayol 2013).

A LOCALLY LED MARINE CONSERVATION REVOLUTION. The

Velondriake LMMA is now serving as a demonstration and learning site for other fishing villages across Madagascar.
Community exchanges facilitated by Blue Ventures and partner NGOs are driving the replication of this approach to locally led marine conservation, with more than 35 other LMMAs established along Madagascar's southern, western and northern coastlines to date (Harris 2011, Mayol 2013).

Meanwhile, the temporary fishery closure model has been embraced by numerous communities; implemented over 150 times along hundreds of kilometres of coastline for reef octopus, and applied to other fisheries including mangrove crabs and spiny lobster in northern and eastern Madagascar. Blue Ventures is pursuing ways of further increasing financial incentives for fishers and seafood collectors to adopt sustainable management practices, with the traditional octopus fishery of southwest Madagascar currently engaged in the Marine Stewardship Council (MSC) eco-certification process (Harris 2011). If successful, this may afford access to premium prices.

FARMING THE SEA FOR ALTERNATIVES TO FISHING. In parallel with these marine resource management initiatives, Blue Ventures has also been developing community-based aquaculture in the Velondriake area since 2007 by connecting local farming teams with private sector partners, and providing them with technical support and business training. Holothuria scabra (sea cucumbers) are initially reared in hatcheries by private sector partner Indian Ocean Trepang (IOT), formerly Madagascar Holothurie, in the regional capital of Toliara. The juveniles are then transferred to community-run pens and grown out until they reach commercial size, when they can be harvested for international export to Asian markets by seafood collection company Copefrito (Robinson and Pascal 2009). In addition, Kappaphycus alvarezii (red seaweed) is cultivated along lines before being dried and sold to copefrito.

Challenges relating to high levels of juvenile holothurian mortality following transfer to lagoonal enclosures are being addressed through the culling of predatory crabs and a number of technical improvements to pen design, which have been successful in increasing survivorship from $40 \%$ to $77 \%$ (Rougier et al. 2013). Loss of sea cucumbers through theft is another major challenge for this programme as these are highly valuable commodities with numerous traders operating in the region, and wild stocks are severely overexploited (Robinson and Pascal 2009). Farmers are tackling this problem by constructing watchtowers from which to monitor their pens, and implementing a rotation system of night guarding involving members of all farming teams in order to identify and penalise poachers (Rougier et al. 2013).

THE FREEDOM TO CHOOSE: UPHOLDING REPRODUCTIVE RIGHTS. In direct response to unmet reproductive health needs expressed by community members across the Velondriake LMMA, and following extensive local consultations, Blue Ventures launched a voluntary family planning service in the central village of Andavadoaka in August 2007 with the approval of community leaders and government health authorities (Mohan and Shellard 2014). The weekly drop-in clinic offers counselling and short-term contraceptive options (condoms, oral contraceptive pills and hormonal injections). Uptake of this service has been positive, with $20 \%$ of women of reproductive age from the village attending on the inaugural day alone (ibid). The opening of this clinic marked the beginning of Blue Ventures' reproductive 
health programme, which enables women and their partners to choose the number and spacing of their births, and has therefore come to be known locally as Safidy, which means 'the freedom to choose'.

With a broad absence of social barriers to the uptake of family planning services and significant demand from other villages, Blue Ventures went on to establish two fortnightly satellite clinics in April 2009, with further clinic sites added between 2010 and 2012. The service area expanded in May 2013 to include villages south of the velondriake boundary where the Wildlife Conservation Society (WCS) and the World Wildlife Fund (WWF) are running community-based conservation programmes, in order to cover a total of 40 communities, home to approximately 15,000 people (Figure 1).

Long-acting reversible contraceptives (hormonal implants and intra-uterine devices) have been offered on a quarterly basis since September 2009, in partnership with Marie Stopes Madagascar's mobile outreach teams: health professionals who travel to remote villages by $4 \times 4$ in order to offer free or subsidised contraceptive services (Marie Stopes International 2014). Blue Ventures is responsible for informing communities about this service. Long-acting reversible contraceptives broaden the range of methods available, reduce the risk of contraceptive failure through inadequate compliance, and address the considerable logistical challenges of providing regular clinics in the more isolated parts of Velondriake (Harris et al. 2012).

COMMUNITY HEALTH WORKERS TRAINED TO PROVIDE VILLAGE-LEVEL SERVICES. In view of the resource-intensive nature of clinic-based service delivery, a different approach was needed in order to meet the significant demand for counselling and contraceptives across such a large and remote area. Shifting the provision of short-term contraceptive methods to community health workers is recommended to improve access to family planning in resource-poor settings (IRIN News 2013, World Health Organization 2013). Blue Ventures therefore decided to introduce community-based reproductive health service delivery in Velondriake by recruiting and training 33 local women as community-based distributors (CBDS) of contraceptives in June 2010, in collaboration with Population Services International (PSI).

These CBDs are able to offer condoms, oral contraceptive pills and hormonal injections according to clear protocols and guidelines; they are supplied with these products at cost price and sell them to clients at very affordable retail prices set by PSI. For example, a one-month pack of oral contraceptive pills is sold for 100 MGA, which is approximately $\$$ USO.05. This provides the CBDs with a little financial compensation for their otherwise voluntary work. They submit monthly reports to Blue ventures, which are collated and shared with the Ministry of Health, and attend quarterly review training sessions run by Blue Ventures' midwife for quality assurance in line with national best practice (Gallo et al. 2013). Thanks to the extensive coverage provided by CBDS, all villages within the velondriake LMMA are now no more than five kilometres from a reproductive health service point. A total of 3,531 clinic consultations and 9,187 CBD consultations were held by the end of the programme's sixth year in July 2013 , with a significant and growing preference for community-based services (Figure 2).

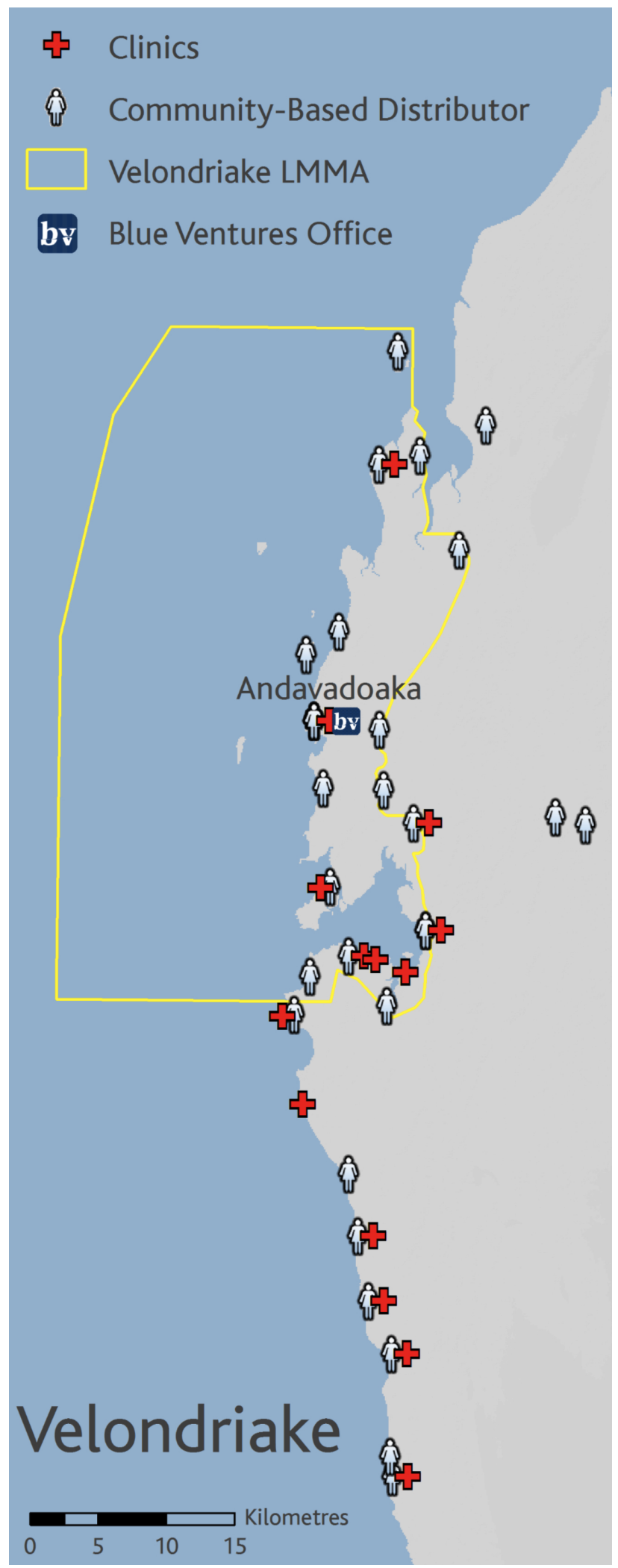

Figure 1. The Safidy programme service area.

CONNECTING THE DOTS: INTEGRATION IN PRACTICE. All of these initiatives, from marine resource management and aquaculture to family planning, are underpinned by a programme of community education, designed to promote the uptake of healthier and more environmentally sustainable practices. Village outreach tours have been running since August 2011, with health and conservation staff engaging over 5,000 community members 


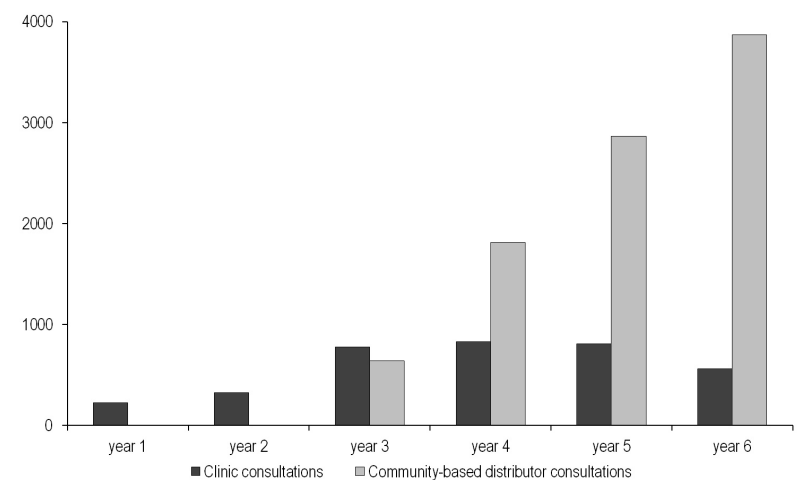

Figure 2. Number of clinic and community-based distributor consultations held by the Safidy programme in Velondriake between mid 2007 and mid 2013.

across the Velondriake LMMA every quarter through school workshops, youth club sessions and interactive presentations using music, drama, films and educational games (Mohan and Shellard 2014). Combining health, livelihood and environmental topics enables the organisation to reach broader audiences. For example, discussions about the links between reproductive health and food security involve women in decision-making about fisheries management and men in family planning (ibid). These educational activities form the cornerstone of Blue Ventures integrated Population-Health-Environment (PHE) approach, which enables the organisation to engage with communities through a variety of entry points and thereby strengthen participation across the breadth of its programmes.

In addition to village outreach tours, peer education by CBDs targets people at all stages of the behaviour change process, from raising awareness to encouraging the sustained adoption of healthier and more environmentally responsible behaviours. This is further complemented by social marketing campaigns, with promotional merchandise such as t-shirts and pirogue sails branded with illustrations depicting key conservation and health messages, designed to positively influence attitudes and practices (Andriamalala et al. 2013). Frequent radio broadcasts featuring songs and short theatre sketches are also used to reach isolated populations with information, promote discussion and support behaviour change.

Conservation, fisheries, aquaculture, health and education staff based in the central village of Andavadoaka hold weekly meetings to ensure regular information exchange and coordination of activities, with internal monthly news updates from programme managers to the entire team. Joint field missions allow programmes to 'boat pool' or 'car pool', thus reducing travel costs and facilitating the sharing of staff or equipment such as generators and projectors. The organisation's annual three-day conference brings together its entire Madagascar team to reflect on progress made across all programmes, and to identify further opportunities for cross-sector working.

\section{IMPACTS}

TEMPORARY OCTOPUS FISHERY CLOSURES. Data collected

from eight years (2004-2012) of temporary octopus fishery closures and over 250,000 landed octopus in southwest Madagascar demonstrate significant closure effects in site-based fishery patterns and village-level incomes, with catch per unit effort and revenues increasing significantly in the month following octopus reserve openings, and no major decline in revenues during the closures (Oliver et al. In lit.).
SEAWEED AND SEA CUCUMBER FARMING. Aquaculture is proving to be an economically lucrative and socially viable livelihood activity in the Velondriake LMMA, with 184 farming teams earning over $\$ U S 10,000$ in 2012, and participants reporting a reduced reliance on fishing for income-generation (Tampolove Village Leader, pers. comm.).

REPRODUCTIVE HEALTH SERVICE PROVISION. A total of 9,730 oral contraceptive pill packs (each providing one month of contraceptive protection), 3,101 depo-provera injections (each providing three months of contraceptive protection), 293 implanon implants (each providing up to three years of contraceptive protection) and 60 intra-uterine devices (each providing up to ten years of contraceptive protection) were provided through the Safidy programme between August 2007 and July 2013 (Mohan and Shellard 2014); equivalent to 2,432.4 couple years of protection (Figure 3). One couple year of protection represents one year of protection from unintended pregnancy for one couple, calculated by multiplying the number of contraceptives distributed by conversion factors relating to the duration of protection offered and the risk of inadequate compliance or contraceptive failure (Stover et al. 2000, Corby et al. 2009, USAID 2011).

Preliminary, anecdotal reports from community members and programme staff in Velondriake suggest that this integrated PHE approach enables couples to plan and better provide for their families, empowers women, improves food security and directly supports the sustainability of local conservation efforts. Should couples choose to space or limit their births, anthropogenic pressure on natural resources is reduced. The distribution of contraceptives through the Safidy programme between August 2007 and July 2013 is estimated to have averted a total of 804 unintended pregnancies among a population of approximately 15,000 people, calculated using Marie Stopes International's Impact 2 toolkit.

WOMEN'S EMPOWERMENT. As women gain access to family planning services, they report acquiring a greater sense of self-efficacy, and being able to spend more time engaging in income-generating and marine resource management activities by spacing or limiting their births (Safidy Community Organiser, pers. comm.). This particularly applies to the organisation of temporary octopus fishery closures and aquaculture farms, both of which involve high levels of female participation (Robinson and Pascal 2009, Barnes-Mauthe et al. 2013). Revenues generated through octopus gleaning and aquaculture are typically used by

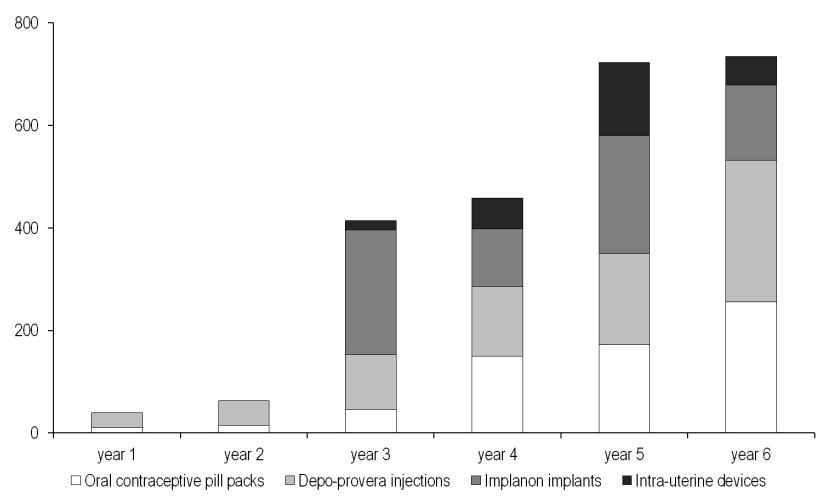

Figure 3. Number of couple years of protection provided by the Safidy programme in Velondriake between mid 2007 and mid 2013. 
women to purchase food, reinforce houses and pay for children's education or medical care (Westerman et al. 2012). These findings correspond with evidence from studies of PHE programmes in the Philippines and Ethiopia, which show that integrating reproductive health services with sustainable livelihood and environmental initiatives can alleviate income poverty and empower women to play a more active role in natural resource management ( $D^{\prime}$ Agnes et al. 2010, Belachew et al. 2013).

Overall, this integrated PHE approach is reported to enable Velondriake communities to live more healthily and sustainably alongside the marine environment upon which their livelihoods depend. "Family planning lets couple choose how many children they have, while marine reserves help to increase fish catches. If the population isn't growing so rapidly and the fish catches are increasing, then we can have a better balance between fish stocks and our population. This means that people and the environment can live together, and we all benefit from this" (President of the Velondriake Association, pers. comm.).

A WIN-WIN FOR CONSERVATION AND HEALTH AGENCIES: PARTNERSHIPS DRIVE ADOPTION. Strong cross-sector partner-ships have been fundamental to the development of this integrated PHE approach in Velondriake. Academic institutions such as the University of Toliara's IHSM, private sector partners such as Copefrito and IOT, health agencies such as Marie Stopes Madagascar and PSI, and conservation organisations such as WCS and WWF all contribute their respective expertise alongside Blue Ventures' interdisciplinary team. This experience demonstrates how the integration of community-based reproductive health services with locally led conservation initiatives can be a win-win approach for conservation and health agencies alike.

From an environmental perspective, the immediacy of reproductive health service benefits to Velondriake communities is reported to help bolster long-term support for the relatively 'slower-burn' progress of local conservation initiatives (Blue Ventures' Conservation Coordinator, pers. comm.). Communities are also seen to be healthier now, and therefore more able to engage in natural resource management activities than before these services were introduced (Blue Ventures' Medical Director, pers. comm.). From a health perspective, partnering with a wellestablished conservation organisation working in a highly remote and under-served area has enabled the delivery of family planning services to reach otherwise hard to reach populations, through leveraging Blue Ventures' existing operational infrastructure and strong community relations (Marie Stopes Madagascar Country Director, pers. comm.).

\section{CONCLUSION}

Blue Ventures' integrated approach to community-based conservation and development has evolved progressively in the velondriake area through a decade of engaging with local communities, understanding their needs and the threats to the ecosystems upon which their livelihoods depend, and supporting them to implement pragmatic solutions in collaboration with numerous partners. The learning derived from this experience has been distilled into a replicable PHE model, which Blue Ventures is now expanding further north along Madagascar's western coastline in the Belo sur Mer area; integrating community-based reproductive health services and aquaculture trials with existing mangrove fishery management efforts.
By mirroring the inextricable links between people, their health and the environment, PHE offers a powerful and locally adaptable way of supporting community-based conservation and development. There is great potential for replicating this integrated model in other marine and terrestrial biodiversity hotspots throughout Madagascar, with growing recognition among conservation and health agencies of the mutually beneficial synergies that can be generated through cross-sector partnerships. For example, the Duke Lemur Center recently started collaborating with Marie Stopes Madagascar's community health workers in order to provide remote villages around Marojejy National Park in the Sava region of northern Madagascar with access to contraceptives (Welch and Patel 2013), and Blue Ventures is supporting other organisations to explore similar partnerships through the Madagascar PHE Network. Such holistic initiatives break the mould with their joined-up thinking; bridging traditional siloes to address unmet family planning needs, uphold women's reproductive rights, and directly support the sustainability of community-based natural resource management efforts by enabling couples to freely choose the number and spacing of their births. Now is the time to scale up this integrated approach in order to safeguard Madagascar's unique natural heritage, and the irreplaceably diverse ecosystems upon which the livelihoods of millions depend.

\section{ACKNOWLEDGEMENTS}

We extend our thanks to Joerg Ganzhorn and Erik Patel for inviting us to contribute to this special issue, and to Ian Colquhoun, Josia Razafindramanana, Lena Reibelt and Juliane Novack for coordinating our inclusion. Thanks also to Alasdair Harris for input on the manuscript, to Garth Cripps and Brian Jones for their photos, and to Leah Glass for the map. The activities described in this paper have been made possible through the invaluable support of numerous partners; several are mentioned in the manuscript and a full list is available on Blue Ventures' website: www.blueventures.org.

\section{REFERENCES}

Agarwal, K. 2013. Allowing women to nurture themselves and their children before giving birth again. USAID Blog. Available at <http://blog.usaid.gov/2013/05/allowing-women-to-nurture-themselvesand-their-children-before-giving-birth-again>

Ahmed, S., Li, Q., Liu, L. and Tsui, A. O. 2012. Maternal deaths averted by contraceptive use: an analysis of 172 countries. Lancet 380, 9837: 111-125 Available at <http://www.thelancet.com/journals/a/article/PIIS01406736(12)60478-4/fulltext>

Andriamalala, G. and Gardner, C. J. 2010. L'utilisation du dina comme outil de gouvernance des ressources naturelles: leçons tirés de Velondriake, sudouest de Madagascar. Tropical Conservation Science 3, 4: 447-472.

Andriamalala, G., Peabody, S., Gardner, C. J. and Westerman, K. 2013. Using social marketing to foster sustainable behaviour in traditional fishing communities of southwest Madagascar. Conservation Evidence 10: 37-41.

Astuti, R. 1995. People of the Sea: Identity and Descent Among the Vezo of Madagascar. Cambridge University Press, Cambridge, UK.

Barnes-Mauthe, M., Oleson, K. L. L. and Zafindrasilivonona, B. 2013. The tota economic value of small-scale fisheries with a characterization of postlanding trends: An application in Madagascar with global relevance. Fisheries Research 147: 175-185. (doi:10.1016/j.fishres.2013.05.011) 
Belachew, T., Sinaga, M., Mohammed, A., Teklu, N. and Stelljes, K. 2013. Effectiveness of the PHE approach for achieving family planning and fertility outcomes in Ethiopia: a comparative study in the Gurage zone. MEASURE Evaluation PRH Working Paper Series. Available at <http://www.cpc.unc.edu/measure/publications/wp-13-134>

Benbow, S., Humber, F., Oliver, T., Oleson, K., Raberinary, D., Nadon, M., Ratsimbazafy, H. and Harris, A. 2014. Lessons learnt from experimental temporary octopus fishing closures in southwest Madagascar. benefits of concurrent closures. African Journal of Marine Science 36, 1: 31-37. (doi:10.2989/1814232X.2014.893256)

Cooke, A., Ratomahenina, O. and Ranaivosion, E. 2000. Madagascar. In: Seas at the Millennium, C. Sheppard (ed.), pp 113-131. Elsevier Science Press, Oxford, UK.

Corby, N., Boler, T. and Hovig, D., 2009. The MSI impact calculator. methodology and assumptions. Available at $<$ http://www.mariestopes.org/sites/default/files/MSI impact calculator _methodology.pdf>

D’Agnes, L., D'Agnes, H., Schwartz, J. B., Amarillo, M. L. and Castro, J. 2010. Integrated management of coastal resources and human health yields added value: a comparative study in Palawan (Philippines). Environmental Conservation 37, 4: 398-409. (doi:10.1017/S0376892910000779)

Gallo, M. F., Walldorf, J., Kolesar, R., Agarwal, A., Kourtis, A. P., Jamieson, D. J. and Finlay, A. 2013. Evaluation of a volunteer community-based health worker program for providing contraceptive services in Madagascar. Contraception 88, 5: 657-665. (doi:10.1016/j.contraception.2013.06.008)

Harris, A. 2007. "To live with the sea": development of the Velondriake community-managed protected area network, southwest Madagascar. Madagascar Conservation \& Development 2, 1: 43-49. (doi:10.4314/239)

Harris, A. 2011. Out of sight but no longer out of mind: A climate of change for marine conservation in Madagascar. Madagascar Conservation \& Development 6, 1: 7-14. (doi:10.4314/mcd.v6i1.68058)

Harris, A., Mohan, V., Flanagan, M. and Hill, R. 2012. Integrating family planning service provision into community-based marine conservation. Oryx 46, 2 : 179-186. (doi:10.1017/S0030605311000925)

INSTAT. 2010. Enquête démographique et de santé: Madagascar 2008-2009. Institut National de la Statistique, Antananarivo, Madagascar. Available at $<$ http://www.instat.mg/pdf/eds2008-2009.pdf>

IRIN News. 2012. Madagascar. A Decaying Health Sector. IRIN News. Available at $<$ http://www.irinnews.org/report/95533/madagascar-a-decaying-healthsector>

IRIN News. 2013. Volunteer Health Workers Filling the Void in Madagascar. IRIN News. Available at <http://www.irinnews.org/report/98482/volunteerhealth-workers-filling-the-void-in-madagascar>

L'Haridon, L. 2006. Evolution de la Collecte de Poulpe sur la Côte Sud-ouest de Madagascar: Eléments de Réflexion pour une Meilleure Gestion des Ressources. Blue Ventures Conservation report. Available at $<$ http://blueventures.org/downloads/bv-research-report-2006-haridoncopefrito-report fr.pdf>

Le Manach, F., Gough, C., Harris, A., Humber, F., Harper, S. and Zeller, D. 2012. Unreported fishing, hungry people and political turmoil: the recipe for a food security crisis in Madagascar? Marine Policy 36, 1: 218-225. (doi:10.1016/j.marpol.2011.05.007)

Marie Stopes International. 2014. Clinical Outreach. <http://mariestopes.org/what-we-do/clinical-outreach> accessed 6 August 2014.

Mayol, T. 2013. Madagascar's nascent locally managed marine area network Madagascar Conservation \& Development 8, 2: 91-95. (doi:10.4314/mcd.v8i2.8)

Mohan, V. and Shellard, T. 2014. Providing family planning services to remote communities in areas of high biodiversity through a Population-HealthEnvironment programme in Madagascar. Reproductive Health Matters 22 43: 93-103. (doi:10.1016/S0968-8080(14)43766-2)

Robinson, G. and Pascal, B. 2009. From hatchery to community: Madagascar's first village-based holothurian mariculture programme. SPC Beche-de-Mer Information Bulletin 29: 38-43. Available at <http://www.spc.int/DigitalLibrary/Doc/FAME/InfoBull/BDM/29/BDM29_38 Robinson.pdf>
Rougier, A., Ateweberhan, M. and Harris, A. 2013. Strategies for improving survivorship of hatchery-reared juvenile Holothuria scabra in communitymanaged sea cucumber farms. SPC Bêche-de-mer Information Bulletin 33 14-22. Available at <http://www.spc.int/DigitalLibrary/Doc/FAME/InfoBull/BDM/33/BDM33.pdf>

Setty-Venugopal, V. and Upadhyay, U. D. 2002. Birth Spacing: Three to Five Saves. Lives. Population Reports Series L, 13: 1-23. Available at <http://www.k4health.org/sites/default/files/13.pdf>

Stover, J., Bertrand, J. T. and Shelton, J. D. 2000. Empirically based conversion factors for calculating couple years of protection. Evaluation Review 24, 1 : 3-46. (doi:10.1177/0193841X0002400101)

UNFPA. 2011. State of the World's Midwifery Report: Madagascar Overview. Available at

$<$ http://www.unfpa.org/sowmy/resources/docs/country_info/profile/en_Ma dagascar_SowMy_Profile.pdf>

USAID. 2011. Family planning and reproductive health indicators database: updated couple years of protection (CYP) conversion factors. MEASURE Evaluation PRH. Available at $<$ http://www.cpc.unc.edu/measure/prh/rh_indicators/specific/fp/cyp>

USAID, World Health Organization and UNFPA. 2009. Family planning for health and development. Available at <http://www.fhi360.org/sites/default/files/media/documents/familyplanning-health-development-uganda-conference.pdf>

Welch, C. and Patel, E. 2013. Marie Stopes International: A new collaboration. Duke Lemur Center's SAVA Conservation Newsletter 2, 3:2-3. Available at <http://www.connect-technology.net/Clients/SAVA/Nov2013/index.html>

Westerman, K., Oleson, K. L. L. and Harris, A. 2012. Building socio-ecological resilience to climate change through community-based coastal conservation and development: Experiences in southern Madagascar. Western Indian Ocean Journal of Marine Science 11, 1: 87-97.

World Health Organization. 2013. Task Shifting to Improve Access to Contraceptive Methods. World Health Organization report. Available at <http://apps.who.int/iris/bitstream/10665/94831/1/WHO_RHR_13.20_eng.p df $>$ 